\title{
PRINCIPLES OF CONCEPT FATE ACTUALIZATION IN ENGLISH LANGUAGE CONSCIOUSNESS
}

\author{
Mariia Ivanchenko \\ PhD (Linguistics), Associate Professor at the Department of Foreign Languages and \\ Translation Lviv State University of Life Safety (Lviv, Ukraine) \\ e-mail: ivanchenkomaria05@gmail.com \\ ORCID: 0000-0001-7363-4600
}

The article deals with principles of fate actualization in English. The research data includes examples collected through the complete selection from dictionaries, thesaurus of English metaphors, fiction texts etc. All examples are divided into blocks according to the actualized phenomenon: "fate-luck», "fate-failure», "fate - doom, inevitability», «man - the master of his destiny». The analysis showed that fate in English is actualized by metaphors, which are formed by verbs in the semantics of which there is a seme "(quickly) move in space» - o fall, to throw, to swim, to escape, to run; adjectives with the seme "poor quality»ill; «desired»-full; adverbs - down, through; nouns, which contain the semes "vague, blurred»-ghost, fade.

Keywords: metaphor; actualization; culture; expression; national specifics.

\section{Іванченко Марія. Принципи актуалізації концепту ДОЛЯ в англійській мовній свідомості.}

Етнічний світогляд як фундамент людської свідомості формується разом із духовною та матеріальною культурою. Усе це відбивається в мові, адже вона є не тільки відомою системою прийомів пізнання, а загалом вважається шляхом усвідомлення естетичних і моральних ідеалів.

«Доля» належить до найдавніших ключових слів нашої культури, які, незважаючи на зміну уявлень людини про світ, а також змін у самому світі $і$ в самій людині, уперто не хочуть зникати з мови і смислового простору культури.

Мовний матеріал складають метафори, завдяки яким можливо виявити приховані від безпосереднього спостереження різні ознаки, щэо об'єктивують ией концепт у мові. Завдяки подібним репрезентаціям ми маємо можливість не лише виявити в максимальному об 'ємі ознаки конщепту, а й викрити його багатовимірну та багатошарову структуру; окрім того, вони дають інформацію про оиінки, трактування, судження, котрі вибудовуються на базі ключових слів лінгвокультури.

Усі інвентаризовані метафори ми умовно об'єднали у смислові блоки відповідно до актуалізованого феномену. Зокрема, найчисельнімою є група метафор «доля удача». Цей феномен тлумачиться як позитивний, бажаний результат чого-небудь, щасливий збіг обставин для когось; успіх. Окрему групу формують метафори протилежного значення, зокрема «доля - невдача». Приклади иієї групи актуалізують невдале, безуспішне, не таке, як хтось бажав, закінчення, завершення чого-небудь. Доля також мислиться як сила, щз визначає подї людського життя, керує ними, щзо зумовило утворення метафор «доля - приречення, неминучість».

Групу метафор «людина - господар своєї долі» складають приклади, у яких описані причинно-наслідкові зв'язки подій у житті особистості залежно від ї̈ поведінки.

Проведений аналіз засвідчив, щзо ДОЛЯ в англійській мові актуалізується за допомогою метафор, утворених за допомогою дієслів, у семантииі яких наявна сема «(швидко) переміщатися у просторі» - to fall, to throw, to swim, to escape, to run;

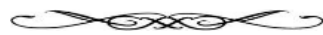

(C) Ivanchenko M., 2020 прикметників із семою «погана якість»-ill; «desired»-full; прислівників - down, through; іменників із семою «розмитість, 
розпливчастість»-ghost, fade. специфіка.

Ключові слова: метафора; актуалізація; культура; вислів; національна

Ethnic worldview as the foundation of human consciousness is formed in conjunction with spiritual and material culture, which are reflected in language, because it is not only a well-known system of cognition methods. Language in general is a way of realizing the aesthetic and moral ideals [Kecskes 2014, p. 91]. Language is the beginning and basis of national self-consciousness, which consists in the cultural heritage of the ethnic groups that formed the nation [Попова, Стернин 2007, p. 67].

'Fate' belongs to the oldest keywords of our culture, which, despite the change of the human world perceptions, as well as changes in the world and in man himself, stubbornly do not want to disappear from the language and culture semantic space [Zykova 2013, p. 429]. The culture keywords historical stability is a consequence of the high stability of the human world picture.

The concept FATE has been already researched by many scientists, such as V. Moskvin, A. Shmelev, A. Vezhbytska, N. Arutyunova, T. Radzievska, M. Glovinska, E. Abayeva.

According to the New English Dictionary on Historical Principles, the noun 'Fate' derived from the Latin word fatum «that which has been spoken» [New English Dictionary III, p. 110]. Primary sense of the Latin word is a sentence or doom of the Gods, but it has subsequently used as the equivalent of the Greece word Moira, which originally meaning only a person's 'lot' or 'portion' had come to express the more abstract conception.

Having analyzed the definitions of English dictionaries (Dictionary of American Idioms and Phrasal Verbs (2002), A New English Dictionary on Historical Principles (1888-1933), New Webster's Dictionary and Thesaurus of the English Language (1993)) we've summarized, that 'fate' for English speaking people is considered to be the things, especially bad things, that will happen or have happened to somebody/something; the power that is believed to control everything that happens and that cannot be stopped or changed.

The aim of this scientific research is to find out the principles and means of concept FATE actualization in English. Linguistic material consists of metaphors, thanks to which it is possible to reveal various features hidden from direct observation, which objectify this concept in language. Such representations give us the opportunity not only to identify the concept features, but to expose its multidimensional and multilayered structure as well; in addition, they provide information about assessments, interpretations, judgments, which are based on the keywords of linguistic culture [Khabirova 2018; Lakoff, Johnson 2003].

The metaphors we collected were divided into semantic blocks, according to the actualized phenomenon. So, the most numerous is the group of metaphors «Fateluck». This phenomenon is interpreted as «a positive, desirable result of something, a happy coincidence for someone; success» [ВТССУМ 2005, p. 457]. The analysis showed that a significant number of examples of this group are metaphors formed in the associative plane «luck-easy prey»: Miller).

If he fell overboard he'd come up with his pocket full of fish (James H. Daisy

In the English language consciousness, luck is actualized by the comparison with fishing, which is associated with luck, the opportunity to get easy prey. 
Obviously, such an associative connection was formed due to the specifics of the mentioned professional activity, the success of which is determined not always by the performer skill, but also by objective circumstances.

The net fills though the fisherman sleep (Arnim E. Christopher and Columbus).

Some metaphors «Fate-luck» are formed on the basis of associations with reservoirs and movement along them.

Give a man luck and throw him in the sea (Ellis A. C. \& Stalen J. Death Jag).

In the mentioned examples the reservoir is thought as difficulties for overcoming which luck is needed. Thus, in the following metaphor, success is actualized by the verb 'to swim', which means «move through water by making movements with your arms and legs» [Oxford living dictionaries], in this context means to swim, i.e. «to rise from the depths of the water to its surface or to swim ashore» [New Webster's Dictionary and Thesaurus of the English Language 1993, p. 34].

He needs must swim that is held up by the chin (Hillerman T. People of Darkness).

The basis for the metaphors «Fate-luck» formation were also comparisons with representatives of the fauna, for example:

On the pig's back (Rodinson R. B. Bicycle Shop Murderer),

A son of the white hen (Butler S. Hudibras),

Please the pigs (London J. White Fang), Wife).

You have nothing to do but suck and wag your tail (Jokai M. Dr. Dumany's

The English noun 'sun' means «the light or warmth received from the earth's sun» [Oxford living dictionaries], while the derived adjective 'sunny' has the definition - «bright with sunlight a sunny day» [New Webster's Dictionary and Thesaurus of the English Language]. These lexemes formed the basis for a number of metaphors of the studied group. Example:

The sun shines on both sides of the hedge (Buddha's Tooth. A Thailand Adventure),

The sun will be on our side of the hedge yet (Hillerman T. People of Darkness),

On the sunny side of the hedge (Butler S. Hudibras).

Positively colored events in human life are naturally associated with such physical phenomena as light, heat, which are inherent in the sun. These properties of the celestial body are associated with a sense of satisfaction, joy. In this case, the metaphorical transfer took place in the associative plane «luck-light, warmth».

In some cases, luck is actualized with the help of lexemes, which in their main meaning have a negative connotation. Example:

It's muck to the midden every time. (The luck always goes to those who already have enough) (Ryman E. Doctor Mooze),

He could fall into shit and come up smelling of violets (Woolf V. To the Lighthouse).

Obviously, in these examples, nouns such as 'muck' and 'shit' are used to enhance the emotional impact on the speaker, so the emphasis is on how easy it is to achieve a successful outcome when there is luck.

Another group is formed by metaphors of opposite meaning, namely «Fatefailure». The examples given in this group actualize «unsuccessful, unlucky, not as someone wanted, the end, the completion of something» [ВТССУМ 2005, p. 234]. 
The English adjective with a negative connotation 'ill' means «suffering from an illness or disease or feeling unwell, poor in quality» [Oxford living dictionaries] has become a crucial force for the metaphors «Failure» formation. Metaphorical transfer in such a case occurs in the associative plane «poor quality-unsuccessful». For example, a person who often experiences failures in his life in English is called 'ill-starred', i. e. «born under or influenced by an evil star, ill-fated, tragic, unfortunate» [Wilkinson 2002, p. 219]. In the language consciousness of the British, fate is compared to a star. Thus, in this example, an unfortunate fate is compared by analogy with a star of appropriate quality.

Another example of a harbinger of bad luck is a bird. Historically, in ancient divination, birds such as owls and crows were considered harbingers of 'omen' (Origin: late $16^{\text {th }}$ cent.: from Latin omen [ovmen] omens) [Wilkinson 2002, p. 814] bad news or events. A person who has a reputation as a harbinger of bad luck in English is compared to a bird: a bird of ill omen [Wilkinson 2002, p. 814].

Absence of hope for a happy fate, luck is actualized with the help of nouns, which in their semantics contain the semes «vague, blurred, unclear, barely delineated, illusory». Example:

As much chance as plaiting fog! (Cuze J. Conspiracy),

Not the ghost of a chance! (Ryman E. Doctor Mooze).

Relevant is an example in which the loss of a success chance is actualized as the deprivation of light.

Stand in his light (Trollope A. The Way We Live Now).

The reason for not being able to take advantage of a happy moment in life is sometimes the person itself. Thus, in metaphors, luck is compared to food - chips, or position in space - pitch, which a person spoils, that is "piss - urinate, discharge (something, especially blood) when urinating» [Oxford living dictionaries] or queer «spoil or ruin (an agreement, event, or situation)» [Oxford living dictionaries]. For example:

Piss in/on his chips (Spoil his chances of success) (Wells H. D. War of the Worlds, p. 390),

Queer his pitch (Sharma R. Caterpillar to Butterfly).

The crucial force of some examples formation within the «Fate-failure» metaphors group are historical figures and territorial units. For example, the lack of successful chances in a certain activity is actualized as 'Buckley's chance' [Wilkinson 2002, p. 553]. William Buckley, a historical figure, was an English convict who was transported to Australia. He managed to escape from prison. However, the circumstances were such that he ended up on an island where he lived in an aboriginal community for more than 30 years. That is, William is in even more trouble than just a temporary prison sentence. Thus, Buckley's «chances» are to "run into even bigger problems».

Another example of a passenger who fails on a trip is 'Jonah' [Wilkinson 2002, p. 852]. Jonah, the Old Testament prophet of the Northern Kingdom (referring to the so-called «little prophets»). The oldest of the Jewish prophets, whose writings have survived. And he was the only Old Testament prophet who «tried to flee from God». According to prophecy Jonah spent three days in the whale's belly, which served as a prototype for Christ's three-day stay in the earth. "For as Jonah was three days and three nights in the belly of a huge fish, so the Son of Man will be three days and three nights in the heart of the earth» (Matthew 12: 39-40). This biblical foundation became the basis for the formation of the corresponding associative connection. 
Aberdeenshire is one of the 32 districts of Scotland, located in the northeast of the country. In Scottish folklore, the Buchan Beast is a large cat or phantom cat, whose existence is mentioned to exist in the historic Buchan district of Aberdeenshire in the north-east of Scotland. In 1930, the first records of large cats, with unusual appearance in Britain are made. In Scotland, they are known as Cù Sìth, the coat color is usually dark green [Barber 1999], the size of the average dog or fox, body length - three feet $(0.91 \mathrm{~m})$. These are the cats are mentioned in the following example.

For the same reason that Aberdeenshire cats never drink cream. They never get the chance (Rodinson R. B. Bicycle Shop Murderer).

Chance by analogy is compared to cream - «thick milk product with high fat content, obtained by settling or separation of fresh milk» [ВТССУМ 2005, p. 338], i. e. a food that is limited in volume and, accordingly, valuable. This comparison emphasizes the unfortunate fate, the unavailability of something good, «valuable».

The «Fate-failure» metaphors are based on comparisons with the phrase "as much chance as». It is interesting, that the «low probability of success» by analogy is compared to hell. Obviously, it serves for achieving greater expressiveness of phrase. Example:

as much chance as of striking a match on wet tripe! (Wells H. D. War of the Worlds, p. 760),

as much chance as a snowball in hell! (Wells H. D. War of the Worlds, p. 904),

as much chance as a cat in hell (without claws) (Wells H. D. War of the Worlds, p. 904),

as much chance as a dog with tallow legs chasing an asbestos cat through hell (Wells H. D. War of the Worlds, p. 904).

Fate - is a given, that is, a gift that a person cannot but accept, cannot bypass. As the analysis of the semantic content of the FATE concept has shown, this phenomenon is perceived in the English-speaking consciousness as a doom, an inevitability. As something which is defined, something that cannot be avoided, bypassed, which must come, happen. So, next we will look at a group of metaphors «Fate-doom, inevitability».

Fate is thought as a force that determines the events of human life, controls them. Accordingly, it is associated with celestial bodies, which are inaccessible and, accordingly, terrifying.

He that is born under a three penny planet will never be worth a groat (Rodinson R. B. Bicycle Shop Murderer),

The stars in their courses (London J. White Fang).

As inevitability, the studied concept is actualized as a nature, physics law, i. e. as «objectively existing, constant and necessary relationship between objects, phenomena or processes, arising from their inner nature, essence; regularity» [ВТССУМ 2005, p. 154]. In the following examples, harvesting by analogy is compared with hopelessness, the need to accept the fact:

We must take the crop as it grows (Wells H. D. War of the Worlds).

A futile attempt to avoid the fated events, the place in life that is predetermined is compared with natural processes in the environment:

As a tree falls so must it lie (Sharma R. Caterpillar to Butterfly).

The following example borders on the thematic groups man and nature, as doom is actualized as a way of human food consumption. In this case, the «bitter» 
fate is actualized as leeks, which a person, despite the unpleasant taste «chews-eatsswallows», and thus accepts his fate.

Chew/eat/swallow the leek (Wells H. D. War of the Worlds, p. 726).

The group of metaphors «Man - the master of his destiny» consists of examples that describe the causal relationships of events in the life of an individual depending on his behavior.

Man, personality - a specific living person, which is characterized by consciousness and self-awareness. Personality structure - a set of especially significant mental properties, relationships and actions of man, formed in the process of his development and determine his behavior. The structure of personality includes all the psychological characteristics of man, and all the metaphysical features of his body [Augoustinos 2014, p. 89].

Despite the objective circumstances that do not depend on the person, each individual influences and to some extent adjusts the course of events in its life. Moreover, the individual determines behavioral patterns and scenarios. In this case, the choice takes place. According to the dictionary, to choose - means «pick out (someone or something) as being the best or most appropriate of two or more alternatives» [McGraw-Hill 2002, p. 99]. Aristotle believed that «choice is something that depends on us; it (choice) is clearly linked to the practical behavioral embodiment, but appears as a complex indirect, rather than impulsive process»» [Aristotel's Poetics 2015, p. 100]. He later emphasizes that «they make the best choice and form the best opinion, obviously not the same people, but some make a pretty good impression, but because of debauchery, spoilage do not choose what is needed» [Augoustinos 2014, p. 190].

In fiction and films, there are many compelling illustrations of how a choice made in a critical situation transforms the individual as a whole. V. A. Lefebvre in his work «Algebra of Conscience» offers the following principle of making choice by the individual: «A living being seeks to generate a line of behavior that establishes and maintains a relationship of similarity between him and his model of himself» [Lefebvre 2001, p. 29].

He that looked at the stars fell in the dike, but he that looked on the ground found a purse (Butler S. Hudibras).

In this example, metaphors depict the outcome of events depending on the choices made by the individual. In this particular case, the idealistic perception of reality is opposed to the practical one. To give expressiveness, a rather polar opposition «dike-purse» (cesspool-wallet) is presented.

Oliver Cromwell was an English statesman, soldier and revolutionary. Lord Protector of England in 1653-1658, Puritan leader. Military leader of the Civil War in England, a supporter of parliamentarism, one of the England Parliament army organizers in the fight against the Royal Army during the Civil War. He inspired his soldiers with speeches in which he often used the expression "keep your powder dry» [Wilkinson 2002, p. 82]. With these words, the leader urged his supporters not to hurry, but to be ready to act if necessary. Over time, the utterance has taken root in speech and acquired a somewhat new meaning, now it is used as «Don't leave all to providence».

Activity is the application of one's labor to something. The implementation of the latter by a person involves the achievement of certain results. The metaphorical expression "chance the ducks» in the dictionary «Thesaurus of Traditional English Metaphors» is explained as Do a thing regardless of risk, come what may 
[Wilkinson 2002, p. 436]. That is, a person consciously takes risks in order to achieve a goal, does not obey providence. In other words - «challenges fate».

On the other hand, confronting the circumstances can lead to a negative result. For example, a situation in which a person tries to avoid unwanted results creates even more problems. An illustration of a situation where it would be better to look at the circumstances. In metaphors, such vicissitudes are compared by analogy with the natural phenomena of «thunder and lightning». Example: Butterfly).

Escape the thunder and fall into the lightning (Sharma R. Caterpillar to

Freedom is the ability of a person to act in accordance with his own desires, interests, goals on the basis of objective reality knowledge [Glas 2006, p. 128]. Freedom is the ability to choose options for events. The problem of freedom in the history of philosophy is complicated by the fact that many thinkers have tried to deduce man's duty from the essence of freedom, sought either not to use the concept of freedom at all, or to use it by limiting it in some way. But duty can never flow from freedom itself, but only for ethical reasons [Augoustinos 2014, p. 46].

On the other hand, everything must have certain limits. The result of absolute or «thoughtless» freedom can be self-destruction. That is, freedom as a human possibility must be subordinated, determined by the degree of responsibility of the individual, first of all, ethical considerations.

Give a man rope enough and he'll hang himself (James H. Daisy Miller),

Flew too near the sun (Arnim E. Christopher and Columbus).

These examples illustrate the perniciousness of excessive freedom.

The analysis showed that fate in English is actualized by metaphors, which are formed by verbs in the semantics of which there is a seme «(quickly) move in space» - o fall, to throw, to swim, to escape, to run; adjectives with the seme «poor quality» - ill; «desired» - full; adverbs - down, through; nouns, which contain the semes «vague, blurred»- ghost, fade.

\section{BIBLIOGRAPHIC REFERENCES}

A New English Dictionary on Historical Principles. J. A. Murray (ed.). Oxford, 18881933. Vol. I-XII.

Aristotel's Poetics (2015). Scolar Select. 146 p.

Augoustinos, M. (2014). Social cognition. An integrated introduction. London, 346 p.

Barber, R. (1999). Myths and Legends of the British Isles. Boydell \& Brewer, Incorporated, $604 \mathrm{p}$.

Glas, G. (2006). Person, Personality, Self and Identity: A Philosophically Informed Conceptual Analysis. Journal of Personality Disorders, 20 (2), pp. 126-138.

Johnson-Laird, P. N. (1980). Mental Models in Cognitive Science. Cognitive Science, 4, pp. 71-115.

Kecskes, I. (2014). Language, Culture, and Context. The Routledge Handbook of Language and Culture. Sharifian F. (ed.). London ; New York, pp. 113-129. [Electronic resource]. URL: https://www.routledgehandbooks.com.

Khabirova, E. (2018). Metaphorical terms in the context of linguistic research articles.

XLinguae. European Scientific Language Journal, 11, pp. 499-507. [Electronic resource]. URL: http://www.xlinguae.eu/

Lakoff, G. \& Johnson, M. (2003). Metaphors We Live By. Chicago, 191 p.

Lefebvre, V. A. (2001). Algebra of conscience. Boston, 358 p.

McGraw-Hill (2002). Dictionary of American Idioms and Phrasal Verbs. The McGraw-Hill Companies, Inc. [Electronic resource]. URL: http://english4success.ru.

New Webster's Dictionary and Thesaurus of the English Language. New York, 1993. 


Oxford living dictionaries [Electronic resource].
https://en.oxforddictionaries.com.
Wilkinson, P. R. (2002). Thesaurus of Traditional English Metaphors. ${ }^{\text {nd }}$ ed. London;
New York, 2034 p.
Zykova, I. (2013). Phraseological Meaning as a Mechanism of Cultural Memory.
Research on Phraseology Across Continents, vol. 2, pp. 422-441.
Великий тлумачний словник сучасної української мови (2005). В. Т. Бусел (гол.
ред.). Київ ; Ірпінь, VIII, 1728 с.
Попова, З. Д. и Стернин, И. А. (2007). Когнитивная лингвистика. Москва, 314 с.

\section{SOURCES}

Arnim, E. Christopher and Columbus. URL: www.freeebooks.net/Christopher_and_Columbus.html.

Buddha's Tooth. A Thailand Adventure. URL: www.freeebooks.net/Buddha's_Tooth.html.

Butler, S. Hudibras. URL: www.world-art.ru.

Cuze, J. Conspiracy. URL: www.free-ebooks.net/Conspiracy.html.

Ellis, A. C. \& Stalen, J. Death Jag. URL: www.free-ebooks.net/Death_Jag.html.

Hillerman, T. People of Darkness. URL: www.freeebooks.net/People_of_Darkness.html.

James, H. Daisy Miller. URL: www.free-ebooks.net/Daisy_Miller.html.

Jokai, M. Dr. Dumany's Wife // www.free-ebooks.net/Dr.Dumany's_Wife.html.

London, J. White Fang. URL: www.free-ebooks.net/White_Fang.html.

Norris, F. Blix. URL: www.free-ebooks.net/Blix.html.

Rodinson, R. B. Bicycle Shop Murderer. URL: www.freeebooks.net/Bicycle_Shop_Murderer.html.

Ryman, E. Doctor Mooze. URL: www.free-ebooks.net/Doctor Mooze.html.

Sharma, R. Caterpillar to Butterfly. URL: www.free-

ebooks.net/Caterpillar_to_Butterfly.html.

Trollope, A. The Way We Live Now. URL: www.free-

ebooks.net/The_Way_We_Live_Now.html.

Wells, H. D. War of the Worlds. URL: www.free-

ebooks.net/War_of_the_Worlds.html.

Woolf, $\bar{V}$. To the Lighthouse. URL: www.bookz.ru/authors/To the Lighthouse.html.

Подано до редакиії 15.04.2020 року

Прийнято до друку 11.05.2020 року 